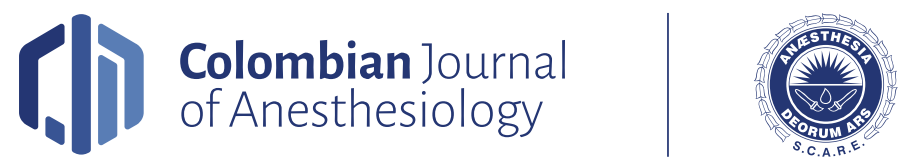

Received: 24 August, 2021 - Accepted: 21 October, 2021 • Online first: 1 December, 2021

DOI: https://doi.org/10.5554/22562087.e1019

\section{How are we doing with anesthesiology recertification in Colombia?}

\section{¿Cómo vamos con la recertificación de los a nestesiólogos en Colombia?}

\section{Luz María Gómez-Buitrago (iD}

Scientific Direction, Colombian Society of Anesthesiology and Resuscitation (S.C.A.R.E.). Bogotá, Colombia

Correspondence: Carrera 15A \# 120-74, Sociedad Colombiana de Anestesiología y Reanimación (S.C.A.R.E.). Bogotá, D. C.

Email: Im.gomez@scare.org.co

How to cite this article:

Gómez-Buitrago LM. How are we doing with anesthesiology recertification in Colombia? Colombian Journal of Anesthesiology. $2022 ; 50:$ e1019.

Over the past seven years, the Colombian Society of Anesthesiology and Resuscitation (Sociedad Colombiana de Anestesiología y Reanimación S.C.A.R.E.) has been at the forefront in the process of anesthesia recertification in Colombia, pursuant to the guidelines of the Colombian Council for Medical Accreditation and Recertification of Specialists and Related Professions (CAMEC). This article aims to provide readers with relevant information regarding some of the milestones achieved and the outlook for what is yet to be done. To fulfill this aim, three aspects that illustrate this valuable experience at S.C.A.R.E. are presented, with the certainty that they will shed light on the road to recertification in Colombia:

1) General considerations regarding anesthesiology recertification;

2) General characterization of anesthetists recertified so far.

3) Reflections on the recertification process, its future and challenges in Colombia.

\section{GENERAL CONSIDERATIONS RECARDING ANESTHESIOLOGY RECERTIFICATION IN COLOMBIA}

In Colombia, the government has been advocating for recertification for several years. When initially enforced, the law of Human Talent in Health (Law 1164 of 2007) considered medical recertification as a requirement for practice. However, since months after it was passed, the Constitutional Court found this requirement unacceptable and judged this provision of the law as unenforceable (1). Later, given the need to create a body to endorse recertification in Colombia, the Colombian Association of Scientific Societies (ACSC) promoted the creation of the Colombian Council for Medical Accreditation and Recertification of Specialists and Related Professions (CAMEC) in 2011. S.C.A.R.E. was part of this second level association from the very beginning, advocating three fundamental principles for recertification: it should be voluntary, conducted by academic peers, and carried out within each scientific society as a transparent and independent process. These principles served as a basis for the rules to be followed by the member societies in initiating their recertification processes; these rules have been revised to a certain extent, but their essence remains (2).

The current basic recertification model is still as first proposed, as shown in Figure 1.

In our case, anesthetists upload the documents (Step 1) that attest to their work towards academic advancement, as defined in the rules, together with a work certificate showing that they are active in clinical practice. S.C.A.R.E. has its own in-house development of an online document center called "ACADEMO" where all the information of the applicants is collected. The documents are reviewed by S.C.A.R.E. and assigned an activity score as required by the rules (Step 2). Once applicants meet the minimum requirement of 500 academic points and 500 work-related points in a 5 -year period, S.C.A.R.E. contacts CAMEC (Step 3) to request issuance of the relevant recertification diploma (Step 4) which is then presented to the anesthetist (Step 5). As the recertifying entity, CAMEC may audit S.C.A.R.E. at any time in order to verify compliance with the regulatory provisions.

Figure 2 shows the academic and work-related activities that count for point allocations. The table of points for each of these items 
FIGURE 1. Basic anesthesiology recertification model.

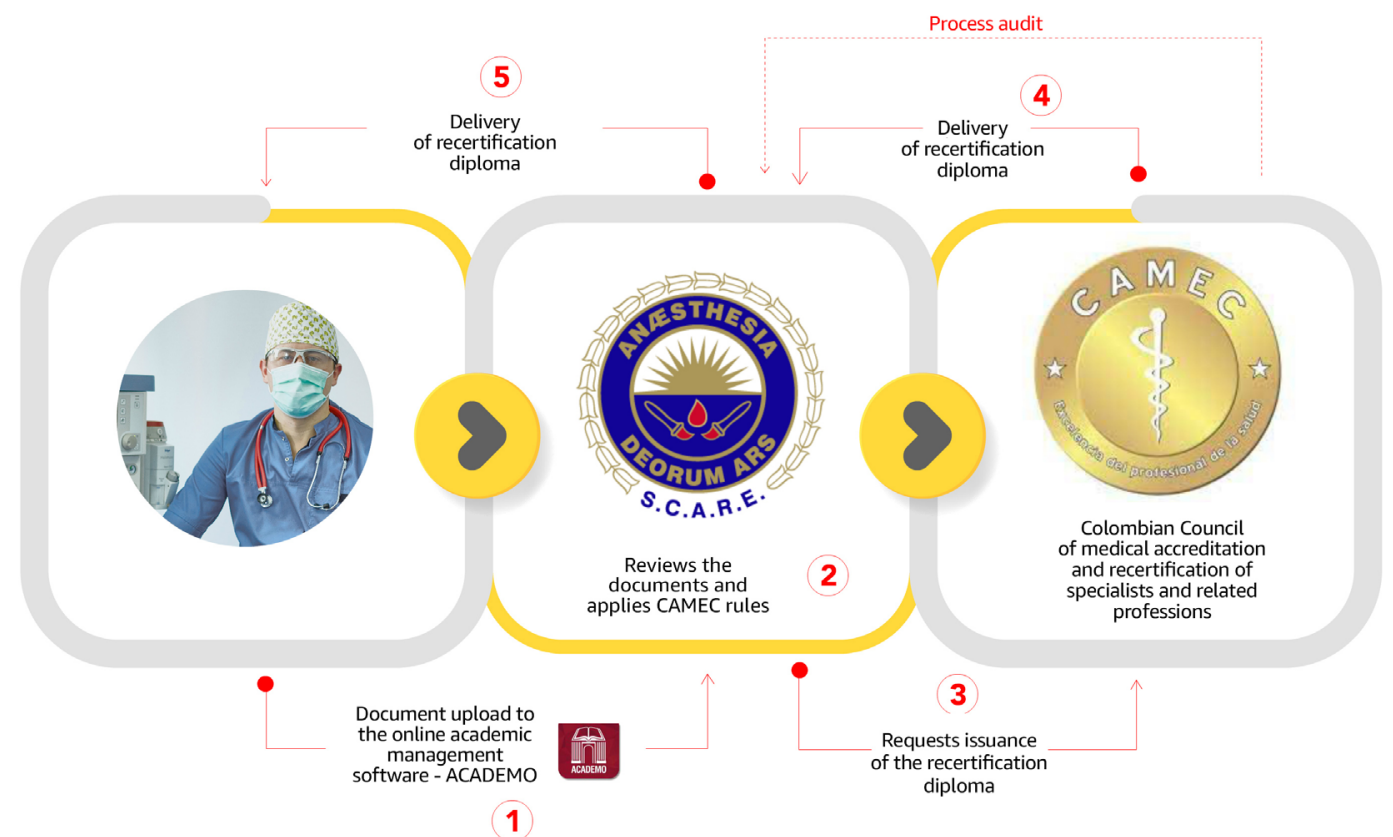

SOURCE: Author.

Ficure2. Academic and work-related points.

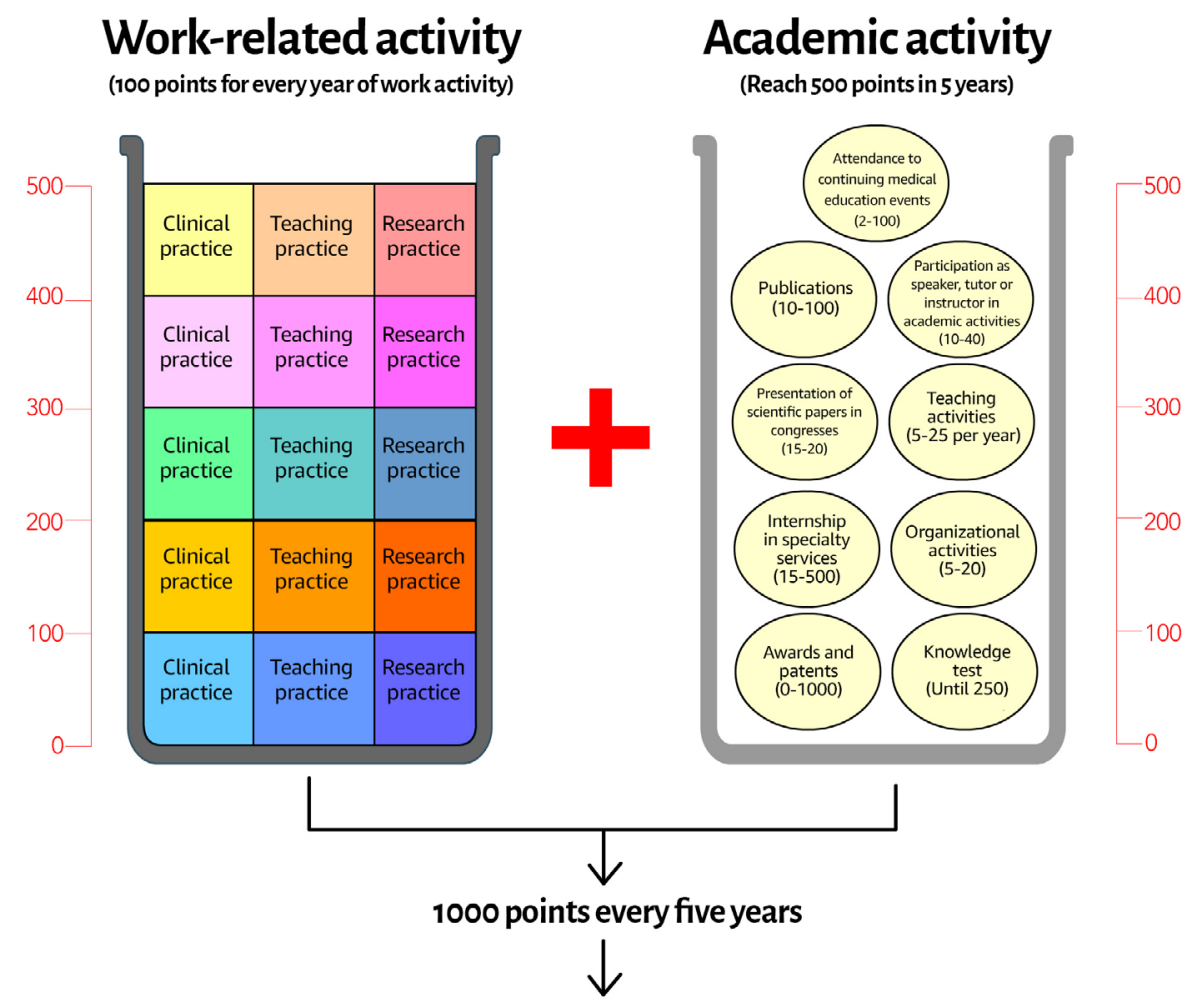

\section{Recertification}

is available at the recertification website (3): https://scare.org.co/recertificacion/

It is worth noting, then, that recertification recognizes the work invested by healthcare professionals - anesthetists in this case - of their own free will in order to remain updated and competent in their knowledge and professional performance, that is to say, in their Continuous Professional Development (CPD).

\section{Why S.C.A.R.E targets recertification?}

Of the many reasons, the most relevant are highlighted below:

- Accreditation by national and international organizations is a trend that has created a culture of accreditation and self-regulation in health and also in education. Users have learnt to trust the endorsement given to an institution by the quality or accreditation stamp issued by validated organizations. The Mandatory Quality in Health System in Colombia has established a precedent in this area, driving health institutions

SOURCE: Author. 
to compete for excellence with the goal of achieving high quality national or international accreditations. Similarly, higher education institutions have been striving to attain high quality accreditation within the education system (4).

- Various publications have shown how knowledge changes over the years and becomes outdated. Knowledge in anesthesiology is no exception and competent professionals must strive to be constant learners in order to remain up to date. Continuing medical education is a good approach, as it has been shown to promote updated knowledge acquisition among healthcare practitioners $\underline{(5)}$.

- Besides the fact that knowledge becomes outdated, neuroscience has shown that the brain forgets and knowledge is difficult to retain for long periods of time. Forgotten knowledge needs to be refreshed, particularly when not used on a regular basis $\underline{(6)}$.

- An international trend is apparent, where different countries have resorted to recertification or revalidation, particularly of healthcare professionals, to ensure that their knowledge base is up to date. Countries and regions like the United States, England, Canada, Australia, New Zealand and the European Union, have been on a long journey towards recertification or revalidation. Although the process is not mandatory in some of those countries, healthcare providers, i.e., healthcare institutions, end up requiring it from their practitioners $(7)$.

- In Colombia, the government has signaled its intention to move towards mandatory recertification since the enforcement of the Human Talent Law, as mentioned initially. Other documents like the "Recommendations for Medical Education Transformation in Colombia" make clear the intention of the academic community to foster mandatory recertification and of the government to embrace such recommendation (8).
- Patient safety requires continuous training and must be supported by knowledge acquisition and evidence-based practices (9). S.C.A.R.E., through its higher mandate, strives to maintain this pillar alive among its members: "We bring together caregivers and foster their growth and professional excellence so that their journey along the healthcare path is characterized by safety, solidarity and humanity".

We are certain that this is a life-long journey and that scientific societies must be there to provide support and encouragement to help pave the way.

\section{GENERAL CHARACTERIZATION OF ANESTHETISTS RECERTIFIED TO THIS DATE}

S.C.A.R.E. initiated its observation window for recertification in 2013. This means that the first group of anesthetists recertified by CAMEC consisted of the cohort that

FiguRE 3. Number of anesthetists earning recertification in each cohort.

\section{Total: $\mathbf{4 5 9}$}

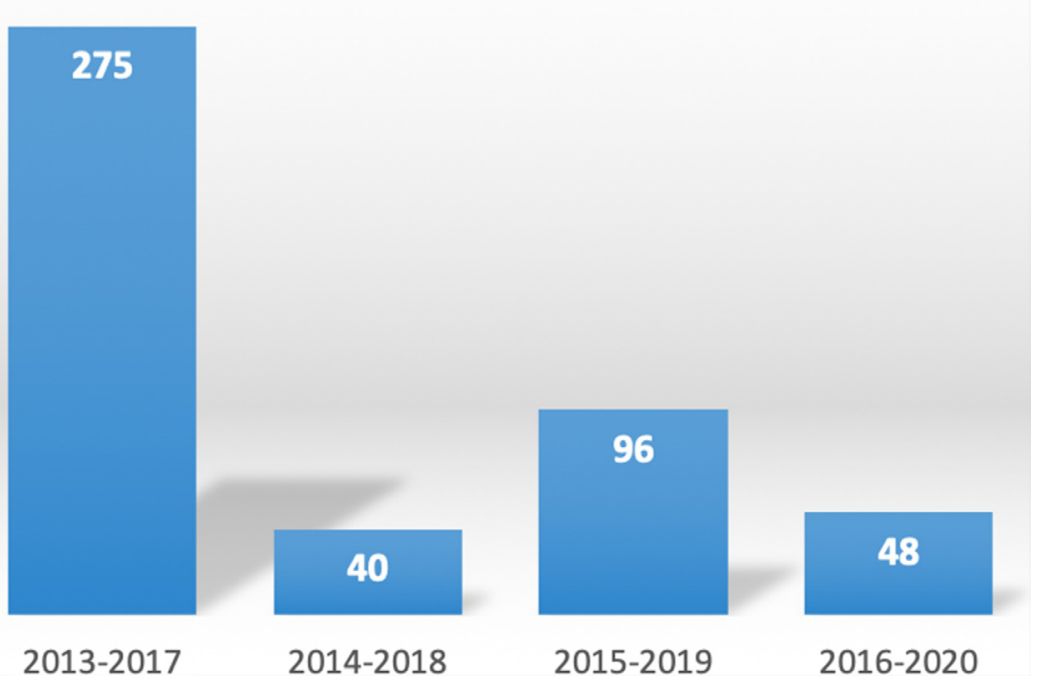

SOURCE: Author. achieved 1000 points for activities performed between January 2013 and December 2017, with 275 anesthetists receiving diplomas. These were followed by 40,96 and 48 in the 2014-2018, 2015-2019 and 2016-2020 cohorts, respectively (Figure 3).

As far as academic points are concerned, $92 \%$ of the anesthetists receiving recertification earned between 500 and 1000 points, $7 \% 1001$ to 1500 , and $1 \%$ achieved a higher score, the highest being 3530 points.

In Colombia, the anesthesia societies of Antioquia and Valle del Cauca boast the highest number of recertified members in absolute terms; however, in relative terms, numbers are significant among the members of the societies of other departments like Quindio, Cesar, Sucre and La Cuajira. The information for each of the societies is broken down by geographic department in Table 1.

Scientific societies from other specialties that are a party to CAMEC have also taken up the leadership in driving 
TABLE 1. Percentage of recertified anesthetists in each of the societies, by department.

\begin{tabular}{|c|c|c|c|}
\hline N. ${ }^{\circ}$ & Department & $\begin{array}{c}\text { Number of recertified } \\
\text { anesthetists }\end{array}$ & Percentage \\
\hline 1 & Antioquia & 93 & $16 \%$ \\
\hline 2 & Atlántico & 26 & $13 \%$ \\
\hline 3 & Bolívar & 19 & $22 \%$ \\
\hline 4 & Boyacá & 4 & $8 \%$ \\
\hline 5 & Caldas & 14 & $16 \%$ \\
\hline 6 & Cauca & 12 & $21 \%$ \\
\hline 7 & Casanare & 0 & ०\% \\
\hline 8 & Cesar & 22 & $32 \%$ \\
\hline 9 & Córdoba & 15 & $25 \%$ \\
\hline 10 & Cundinamarca & 43 & $7 \%$ \\
\hline 11 & Huila & 9 & $15 \%$ \\
\hline 12 & La Guajira & 6 & $30 \%$ \\
\hline 13 & Magdalena & 2 & $6 \%$ \\
\hline 14 & Meta & 7 & $16 \%$ \\
\hline 15 & Nariño & 11 & $16 \%$ \\
\hline 16 & N. de Santander & 14 & $23 \%$ \\
\hline 17 & Quindío & 18 & $50 \%$ \\
\hline 18 & Risaralda & 26 & $28 \%$ \\
\hline 19 & Santander & 28 & $19 \%$ \\
\hline 20 & Sucre & 8 & $31 \%$ \\
\hline 21 & Tolima & 3 & $5 \%$ \\
\hline 22 & Valle del Cauca & 78 & $18 \%$ \\
\hline
\end{tabular}

SOURCE: Author.

recertification among their members For example, there are more than 700 recertified urologists and, according to CAMEC, S.C.A.R.E is second in terms of absolute numbers of recertified specialists, with a total number of 459 to this date.

\section{REFLECTIONS ON THE PROCESS AND THE FUTURE OF RECERTIFICATION IN COLOMBIA}

I would like to focus on the most relevant aspects identified over the past few years and, in particular, on what the future may look like.
- One of the challenges identified by the users of recertification is that document uploading onto any digital platform requires all documents to be in PDF format so that they can be attached as proof, and also to enable tracking of the process. S.C.A.R.E. has wanted to support its members by means of automatic uploading of the activities performed within the organization; however, this has not been possible yet because of technology and operational hurdles.

- The biggest challenge is perhaps the cost of participating in continuous professional development activities, in particular considering the type of agreements under which most anesthetists are hired. Ongoing education depends entirely on the individual's ability to pay, and this is compounded by the fact that attendance to education programs is subject to unpaid leave of absence. This is in contrast to other countries, where healthcare institutions allow protected time for continuing education.

\section{Challenges:}

- A more comprehensive recertification process comprising not only technical knowledge but also soft and hard skills is required. Implementing more educational evaluations in simulation settings to integrate soft and hard skills could be a good approach (10). On the other hand, audits at work or peer verification in clinical practice can also be of help (11). promotion of continuing education and encouraged theleadership of theanesthesia societies in the different departments to engage in academic activities. Although the larger societies have undertaken these activities regularly, others have identified academic events as a means to offer their members opportunities to obtain points for recertification. The growing offering of online education as a result of the SARS-CoV2-Covid-19 pandemic has reached distant cities with traditionally low academic activity, an opportunity that has been embraced by anesthetists across the country.
- Another consideration is the specific practice settings of the anesthesia specialists. For example, someone working in cardiovascular anesthesia should only be evaluated for hard skills, and the same may be true in other specific areas. It has not been possible to implement such an approach to this date, but it has been identified as a challenge in want of feasible solutions.

- Another challenge is to offer multiple channels and enhanced accessibility. 
Continuing education must be open to all anesthetists in the country. Online training has offered great possibilities, but it is clear that workshops and simulation activities must be brought to regions with greater access limitations, or ways must be found to make it easy for anesthetists to travel to the places where those activities are offered.

We have made great progress in recertification. We are still convinced that this is a good way to promote safe healthcare and continuous professional development. It is not yet clear if it will become mandatory for all human talent in healthcare, but there is no doubt - as already seen in clinical practice - that the time will come when employers will prefer professionals with up-to-date recertifications as part of their teams, in the same way as they are proud to exhibit Top Quality certifications and other recognitions. A certified workforce may well become their best showcase.

\section{Author's contributions}

LMCB: The author of the paper gathered and analyzed the information and prepared the manuscript.

\section{Assistance for the study}

None declared.

\section{Funding and sponsorship}

None declared.

\section{Conflict of interest}

The author is the Scientific Director of the Colombian Society of Anesthesiology and Resuscitation (S.C.A.R.E.).

\section{Submissions}

None declared.

\section{Appreciation}

To Diana Carolina Torres, Scientific Directorate assistant in charge of supporting the recertification process at S.C.A.R.E. To doctor Gustavo Reyes, S.C.A.R.E. CEO, for the graphic design of Figures 1 and 2.

\section{REFERENCES}

1. González Vega OO. La recertificación médica fue declarada inexequible. ¿Ahora qué sigue? Rev Colomb Gastroenterol. 2008;23(4):306-8.

2. Consejo Colombiano de Acreditación y Recertificación Médica, de Especialistas y Profesiones Afines CAMEC. Reglamento Operativo de Recertificación [internet]. 2016. [cited: 2021 ago. 13]. Available at: http://camec.co/wp/reglamento/

3. Sociedad Colombiana de Anestesiología y Reanimacion (S.C.A.R.E.). Recertificación [internet]. 2020. [cited: 2021 ago. 13]. Available at: https://scare.org.co/recertificacion/

4. Consejo Nacional de Acreditación (CNA), Consejo Nacional de Educación Superior (CESU), Ministerio de Educación de Colombia. Acuerdo 02 de 2020. Por el cual se actualiza el modelo de acreditación en alta calidad [internet].
2020. [cited: 2021 ago. 13]. Available at: https://www.cna.gov.co/1779/articles-402848 documento.pdf

5. Densen P. Challenges and opportunities facing medical education. Trans Am Clin Climatol Assoc. 2011;122(319):48-58.

6. Davis RL, Zhong Y. The biology of forgetting-A perspective. Neuron. 2017;95(3):490503. doi: http://dx.doi.org/10.1016/j.neuron.2017.05.039

7. Roberts L]. Revalidation: Implications for Australian anaesthetists. Anaesth Intensive Care. 2015;43(5):652-61. doi: https://doi.or$\mathrm{g} / 10.1177 / 0310057 \mathrm{X} 1504300516$

8. Comisión para la Transformación de la Educación Médica en Colombia. Documento de recomendaciones para la transformación de la educación médica en Colombia [internet]. 2017. [cited: 2021 ago. 13]. Available at: https://www.minsalud.gov.co/sites/rid/Lists/ BibliotecaDigital/RIDE/VS/MET/recomendaciones-comision-para-la-transformacion.pdf

9. Choudhry NK, Fletcher RH, Soumerai SB. Systematic review: The relationship between clinical experience and quality of health care. Ann Intern Med. 2005;142(4):260-73. doi: https://doi.org/10.7326/0003-4819-142-4200502150-00008

10. Lien CA, Warner MA, Rathmell JP. Simulation for assessment of the practice of board-certified anesthesiologists. Anesthesiology. 2017;127(3):410-2. doi: https://doi.org/10.1097/ ALN.0000000000001792

11. Tzortziou Brown V, McCartney M, Heneghan C. Appraisal and revalidation for UK doctors Time to assess the evidence. BM]. 2020;370:14. doi: https://doi.org/10.1136/bmj.m3415 